\title{
Stress among Brazilian Dental Students in Different Periods: Prevalence and Perceptions
}

\author{
Jean Érick Langoski, Letícia Breus Klipan1, Danielle Bordin², Marcelo Ubiali Ferracioli³, \\ Márcia Helena Baldani Pinto ${ }^{1}$, Cristina Berger Fadel ${ }^{1 *}$ \\ ${ }^{1}$ Departament of Dentistry, State University of Ponta Grossa, Paraná, Brasil \\ ${ }^{2}$ Social and Preventive Dentistry, Paulist State University, Araçatuba, Brasil \\ ${ }^{3}$ Departament of Education, State University of Ponta Grossa, Paraná, Brasil \\ Email: je-erick@hotmail.com, leticia klipan@hotmail.com, daniellebordin@hotmail.com, \\ ferracioli19@gmail.com, marciabaldani@gmail.com, ${ }^{*}$ cbfadel@gmail.com
}

Received 29 January 2015; accepted 23 February 2015; published 26 February 2015

Copyright (C) 2015 by authors and Scientific Research Publishing Inc.

This work is licensed under the Creative Commons Attribution International License (CC BY).

http://creativecommons.org/licenses/by/4.0/

cc) (i) Open Access

\section{Abstract}

The purpose of this exploratory study was to investigate the influence of the school year, considering different times on the academic trajectory of stress among Brazilian dental students $(\mathrm{n}=$ 111) as well as grasp the values established by the subject facing this prospect. The methodological grant for data collection was the Inventory of Stress Symptoms for Adults Lipp applied in the beginning and at the end of the semester, and the technique in the focus group interview. The results demonstrated academic tickets with significantly higher rates of this phenomenon at the end of the semester, when compared to graduates $(p=0.004)$. The perceptions of academics on the etiology of stress associated opinions unveiled the pedagogical design, teacher performance, difficulties in interpersonal relationships as well as the course extrinsic factors. It can be concluded that the stress is the present and modulate phenomenon in investigated academic trajectory.

\section{Keywords}

Disease Susceptibility, Psychological Stress, Dental Students, Stress, Higher Education

${ }^{*}$ Corresponding author. 


\section{Introduction}

The intrinsic mobilization generated to cope with everyday pressures and burdens, coupled with external events and confrontation with the individual profile produces a nonspecific response of the body nominated stress (Selye, 1965).

Studies show that stress arises through a process of steps, in which the symptoms and the form of management are differentiated according to the observed phase (Lipp \& Malagris, 2001). The Brazilian model most often used to the identification and measurement of stress is characterized by the qualifying presence stages, namely: alarm, resistance, exhaustion and near-exhaustion, when the distinction of the same is given by the duration of the action on the stressor and the manifestation of symptoms or organic psychological (Lipp, 2003).

Considering in particular the world of higher academic education, full of new challenges and different confrontations, it is assumed that it can be an important tool to the stress (Lu, 1994). Thus, it is assumed that the environment itself building knowledge, as is the case of higher education institutions can contribute, sometimes for triggering pathological disorders in their students when the exacerbation of the problem of academic stress (Monteiro, Freitas, \& Ribeiro, 2007; Morrison \& O’Connor, 2005).

High stress levels are routinely reported among dentistry students, both in Brazilian studies (Aguiar, 2007; Campos et al., 2012), as in internacional ones (Ah-Saleh et al., 2010; Tangade et al., 2011). The course of the academic experience during the undergraduate years may reveal different stress stages in each study comprisses step (Polychronopoulou \& Divaris, 2005) with variation in the etiology perceived by students (Dahan \& Bedos, 2010).

Based on these and the scarcity of studies that combine quantitative and qualitative methodologies in the profundity of this phenomenon, this study aimed to investigate the influence of the school year on stress among students of dentistry, considering distinct moments of the academic trajectory and grasp the perception of the subjects face this prospect.

\section{Material and Method}

This quantitative and qualitative, exploratory and descriptive study was approved by the Ethics Committee on Research with humans, State University of Ponta Grossa-UEPG (opinion No. 266.128/2013), respecting the dictates of Resolution 466/12 of the National Council of Health.

The study was carried out in two dentistry academic populations from a Brazilian university: first graders and graduating $(\mathrm{n}=111)$. The base year was 2013 for consultation.

Quantitative data were gathered by trained researcher, collectively, at two different times: beginning and end of the semester. It involved the usage of a simple questionnaire exposing information about age and gender; and an instrument with national scientific validation, named "Inventory of Stress Symptoms for Adults Lipp"ISSL (Lipp, 2000). The tabulation of this information followed by the proposed Lipp, being based on a four phasic model (alarm, resistance, half-exhaustion and exhaustion) and proposes a method of stress assessment that emphasizes somatic and psychological symptoms etiologically linked. A descriptive analysis of information was made by frequency distributions with usage of chi-square test for the presence of associations.

For the apprehension of the qualitative information, the technique of focus group interview was used twice (Merton, Fiske, \& Kendall, 1956), with support from an unpublished screenplay, guided by beginners and graduating academics’ perception about agents influencing their college performance. The results were transcribed, analyzed and categorized by the Analysis of Content theme (Bardin, 1979) and discussed with supporting scientific literature.

The subjects were informed about the study objectives, its character and the willingness of non-identification, as well as how to collect, analyze and target data. Those who agreed to participate, a made initially by filing a Statement of Informed Consent and their participation in the quantitative phase of data collection. Only individuals of both groups that showed significant levels of commitment in relation to stress were invited to join the qualitative interview.

\section{Results and Discussion}

The final sample described 107 academics interviewed in the first phase and 104 in the second one, with an average age of 20.5 years old. The loss of individuals was due to the absence at the time of the interview or by re- 
fusing to participate. For the qualitative phase were nineteen distinguished academics, between beginners and graduates, with no refusal by the subjects.

\subsection{In the Quantitative Part}

The episode focused on stress $45 \%$ and $71 \%$ of the students in the first year and $55 \%$ and $60 \%$ of graduating ones, considering the beginning the and end of the semester respectively, with a predominance of phase resistance at both stages (Table 1). The results also showed a hegemony of psychological symptoms, when compared to the physical events (Table 2).

Considering the school year in progress, regardless of position in the academic course, there was no significant relationship with the prevalence of individuals affected by stress $(p=0.132)$. However, scholars have exposed tickets significantly higher rates of this phenomenon at the end of the semester $(p=0.004)$, when compared to graduates $(p=0.614)$. This result corroborates with other findings may suggest literature (Dahan \& Bedos, 2010; Fonseca et al., 2013; Manolova et al., 2012) and better internal accommodation of trainees face the obvious academic demands of this period, as the concentration of evaluative tests and examinations, or be explained by the way a bit more powdered evaluation trainees in that institution.

According with the present study, no differences in the prevalence of stressors symptoms compared to different provisions of the academic course was previously expose (Aguiar, 2007). The prevalence of stress among Brazilian students who attended dentistry was previously traced, exposing similar to the average of the present study (58.5\%) (Calais, Andrade, \& Lipp, 2003).

The predominant here found the resistance phase (83\%) at all times when the stress was evidenced occurred analogously to other study forms (Aguiar, 2007; Carvalho \& Malagris, 2007; Heinz, Damin, \& Silva, 2011; Oliveira et al., 2012) in this stage the organism search physiological homeostasis and also if the stressor is continuous and the individual does not possess strategies to control the frame, the body depletes its reserves of adaptive energy and the exhaustion phase manifests, culminating with the appearance of significant harm to health (Lipp, 2005).

Table 1. Distribution of the prevalence of stress among dentistry students according to academic history and evolution model $^{*}$.

\begin{tabular}{|c|c|c|c|c|c|c|c|c|c|c|c|c|c|c|}
\hline & & \multicolumn{2}{|c|}{$\begin{array}{l}\text { Stress } \\
\text { Free }\end{array}$} & \multicolumn{2}{|c|}{ Stressed } & \multicolumn{2}{|c|}{$\begin{array}{l}\text { Alert } \\
\text { Phase }\end{array}$} & \multicolumn{2}{|c|}{$\begin{array}{l}\text { Resistance } \\
\text { Phase }\end{array}$} & \multicolumn{2}{|c|}{$\begin{array}{c}\text { Half } \\
\text { Exhaustion } \\
\text { Phase }\end{array}$} & \multicolumn{2}{|c|}{$\begin{array}{c}\text { Exhaustion } \\
\text { Phase }\end{array}$} & \multirow{2}{*}{$\begin{array}{c}\text { Total } \\
\text { Sample } \\
\mathrm{n}\end{array}$} \\
\hline & & $\mathrm{n}$ & $\%$ & $\mathrm{n}$ & $\%$ & $\mathrm{n}$ & $\%$ & $\mathrm{n}$ & $\%$ & $\mathrm{n}$ & $\%$ & $\mathrm{n}$ & $\%$ & \\
\hline \multirow{2}{*}{$1^{\text {st }}$ Grade } & Step 1 & 31 & 55 & 25 & 45 & 0 & 0 & 23 & 92 & 2 & 8 & 0 & 0 & 56 \\
\hline & Step 2 & 17 & 29 & 42 & 71 & 3 & 7 & 31 & 74 & 7 & 17 & 1 & 2 & 59 \\
\hline \multirow{2}{*}{$5^{\text {th }}$ Grade } & Step 1 & 23 & 45 & 28 & 55 & 0 & 0 & 25 & 89 & 0 & 0 & 3 & 11 & 51 \\
\hline & Step 2 & 18 & 40 & 27 & 60 & 2 & 7 & 21 & 78 & 3 & 11 & 1 & 4 & 45 \\
\hline
\end{tabular}

${ }^{*}$ Lipp, 2000.

Table 2. Distribution of the prevalence of stress among students of dentistry according to academic trajectory and type of symptom* .

\begin{tabular}{|c|c|c|c|c|c|c|c|c|c|}
\hline & & \multicolumn{2}{|c|}{ Stressed } & \multicolumn{2}{|c|}{$\begin{array}{l}\text { Physical } \\
\text { Symptoms }\end{array}$} & \multicolumn{2}{|c|}{$\begin{array}{l}\text { Psychological } \\
\text { Symptoms }\end{array}$} & \multicolumn{2}{|c|}{$\begin{array}{c}\text { Equivalence } \\
\text { Psychological/Physical }\end{array}$} \\
\hline & & $\mathrm{n}$ & $\%$ & $\mathrm{n}$ & $\%$ & $\mathrm{n}$ & $\%$ & $\mathrm{n}$ & $\%$ \\
\hline \multirow{2}{*}{$1^{\text {st }}$ Grade } & Step 1 & 25 & 45 & 7 & 28 & 17 & 68 & 1 & 4 \\
\hline & Step 2 & 42 & 71 & 13 & 31 & 21 & 50 & 8 & 19 \\
\hline \multirow{2}{*}{$5^{\text {th }}$ Grade } & Step 1 & 28 & 55 & 9 & 32 & 18 & 64 & 1 & 4 \\
\hline & Step 2 & 27 & 60 & 5 & 19 & 19 & 70 & 3 & 11 \\
\hline
\end{tabular}

${ }^{*}$ Lipp, 2000. 
Concerning the nature of the symptoms presented, considering studies with the same investigative method, the literature presents the work with a preponderance of psychological symptoms (Aguiar, 2007; Calais, Andrade, \& Lipp, 2003), in line with the findings of this study as well as studies that show the supremacy of physical events (Carvalho \& Malagris, 2007; Bassols et al., 2008) the psychological symptoms of stress, which seem to be related to the high performance and concentration of effort required during routine constant and increasing studies, could hinder access to necessary academic skills, inferring negatively on formative process (Carvalho \& Malagris, 2007).

\subsection{In the Qualitative Part}

The insights revealed by academics on the allocation of stressors in their academic experience constituted two major dimensions: intrinsic and extrinsic factors to the course.

\section{Intrinsic factors to the course}

Interviewees pointed the teaching didactic project adopted in the course as stressful in largely source of interview. The discourses, concerning every school moment subcategories showed the students discontent in relation to how they are evaluated, the systematization of activities in clinical practice, the excess of theoretical workload, the counterproductive in the distribution of classes and the excessive demand of activities.

Several studies also conducted with academics during dentistry undergraduate, showed the evaluation method as stressor in the university environment, being able to affect deeply student achievement. In these, the associations have made, especially opposition to the exams and scope of unsatisfactory grades (Fonseca et al., 2013; Manolova et al., 2012), the need for completion of minimum clinical requirements (Badran et al., 2010; Pani et al., 2011); to the time required for completing the clinical activities (Dahan \& Bedos, 2010) and the feeling of failure before the quality and quantity of minimum required procedures to the course approval (Al-Saleh et al., 2010; Fonseca et al., 2013; Al-Samadani \& Al-Dharrab, 2013; Al-Sowygh, Alfadley, Al-Saif, \& Al-Wadei, 2013).

"I would appreciate if there were a lighter assessment method, because it is always the same: more evidence and proof. I do not believe the test is the best method to assess whether you have acquired knowledge, because the nervousness at the time of assessment may end up damaging even if you know the story. In most disciplines the evaluation is primarily through evidence; or you will well on the test or you reprove in the matter." ( $1^{\text {st }}$ year student)

"The problem is the lack of criteria for evaluating teacher and hurts it. It only evaluates the best procedure does not take into account the patient's age, the time we have to do.” (Last year student)

"If the freshmen helped, it would improve our performance. Because when we work in pairs in the clinic, we have to divide our time and if they should assist us, we would have an entire year to accomplish the goals, and they would learn more.” (Last year student)

The uneven distribution of the workload over the course of the week, which employs often fragments of up to three daily shifts, and the accumulation of lectures early graduation, aspects were also addressed. The related research also ascribed to poor use of time for the university education, with emphasis on the excessive amount of daily classes and shortage of time for study, a situation which stress can cause fatigue and infer significantly in the context of the academic health (Monteiro, Freitas, \& Ribeiro, 2007; Lazzarin, Nakaman, \& Cordoni Júnior, 2007; Sedky, 2012). This experience of long intervals between classes without a continuity that encourages students to remain in the institution was still considered somewhat fruitful for the respondents, since it cannot use these intervals to perform other activity.

"Since the first year I had to literally travel every day to come to the university. When I came by bus were 4 h per day. I came for a lesson on Monday morning that began a quarter past 8, the other class was only half past thirteen and I had to stay here. I was very stressed.” (Last year student)

"I think it's a lot of theory in the beginning, I understand what it takes, but just have to study and memorize theories at the beginning of the course is complicated. For me the great theoretical load is a factor that must be considered." (1 $1^{\text {st }}$ year student)

The excessive workload during graduation may emerge as another major stressor among college students (Dahan \& Bedos, 2010), unfolding in inherent sense of frustration at the poor time to rest and relax (Al-Saleh, 2010; Polychronopoulou \& Divaris, 2005; Rajab, 2001). Thus, the irregularity between situations with too many 
activities may result in the inability of compliance demands, causing tension and therefore the establishment of stress. In others situations in which the student is faced with times of increased idleness, can generate a confusing perception in individuals and again result in characteristic feelings of stress, such as wear and feel disability (Monteiro, Freitas, \& Ribeiro, 2007).

“I have a thought that those five years I'll have to devote myself entirely to the college, the course demands a lot and I have no way to focus on something else together. I do not have time to do anything but study. I do not spend the weekends without being studying. Besides the veterans speak for us to calm down that gets worse, and I ask myself: my God? How to get worse?” ( $1^{\text {st }}$ year student)

Another stressor elapsed the speeches referred to the conduct of university teachers in the academic environment. The lack of compliance with biosafety regulations, inappropriate behavior in students and patients approach, the divergence between the delegations pairs in clinical activities, clinical inexperience and exacerbated the concentration of decision-making in the face of academic assignments, resulting in sparse student autonomy were highlighted.

The difficulty of faculty and staff fully heeding the biosecurity protocols, aimed at agility during dental treatment, is discontent with perceived by students, since their attitudes and practices of learning during graduation are reflected in these profissionals (Pinelli et al., 2011).

"There are teachers who have no care with contamination, do not use cap, glove, mask, and then complain about the students. These are college standards.” (Last year student)

The interaction of students with faculty, perceived as a source of stress, it is also evident in related international studies (Al-Saleh, Al-Madi, Al-Angari, Al-Shehri, \& Shukri, 2010; Polychronopoulou \& Divaris, 2005; Dahan \& Bedos, 2010). The dental students need to be nurtured and treated as full members of the team of dental care, and therefore contribute the need on the part of educators accomplish great efforts that aim to empathize with their students and the feeling of appreciation (Dahan \& Bedos, 2010). Still, the share of social or sporting activities can be a good way to develop team spirit and engage the student a strategy aimed at building interest in the discipline.

“There are teachers who are more delicate in approach, as much as they want to fight, they call and private conversation, but others do not care, can be in front of the people, it does not matter [...].” (Last year student)

"Another reason is the lack of consensus among teachers of the same as clinical procedures. The patient arrives and you call a teacher and he says to do certain procedure, then you need him and he's not in the room, you call another teacher and he opines very different, causing intrigues among the teachers and between teachers and us.” (Last year student)

There are different stages of student autonomy, which show related to socio-cultural context of students and teachers should be respected (Pesce, 2012). However, the teacher's role in building critical, reflective and society in which they live transformers subject should be well established.

"I think in the 5th grade teachers want to put barriers in the treatment and we cannot work right... They want us to be kind of dependent on them, and it should be the opposite.” (Last year student)

In reference to the role of the teacher-researcher-emphasizes the importance of ongoing education referred to always be related to the context and pedagogical practices concerning teaching and, having thus sense the reflective action on the teaching practices. One hopes that they are able to print certainties and doubts sanitize, minimizing the difficulties facing students, urging personal values and transmitting experience (Lima, 2007). Despite the theoretical ability of the teachers have not been questioned by the interviewees, the practical difficulties domain, opposite the given theory, embodied the discourses.

"We do not deny the intelligence of teachers, if they are in the clinic with master's and doctorate, but with no practice, there's no results.” (Last year student)

Another stressor element intrinsic to graduation was the difficulty in interpersonal relationships, elucidated by the lack of closeness between colleagues and differences of opinion.

Some universities prepares the individual for the changes that occur after high school, because they offer poor investments in pedagogical practices and do not provide programs that foster student's psychosocial adaptation 
(Gerk \& Cunha 2006). An alternative pointed out by respondents seeking ease the difficulties in social relationships, in especially in the early years of graduation, was the removal of traditional anchoring students in practical classes, which would favor the approach with different subjects.

“There's plenty of people who feel cornered because they cannot express their own opinion by virtue of not having rapprochement and coexistence with others, they would express more if they had more approach.” ( $1^{\text {st }}$ year student)

“I think you feel much better in practical classes. I like histology, I’m happy when I have histology practice class, but when I have another lecture material, the feeling is different now, I think: that will be boring for everyone." ( $1^{\text {st }}$ year student)

It is believed that the basis for favorable interactions in teaching and learning should be guided by democratic, fair criteria and mutual respect, by the practices cordiality existence. In this context, it is worth noting the importance for the teacher, observing the attention devoted to the planning of classroom interactions that promote socialization among students and appreciation of individuals and collectivities.

“In our classroom people don’t talk, people fight, they always want to impose opinion. That's what always happens and cause the discussions." ( $1^{\text {st }}$ year student)

\section{Extrinsic factors to the course}

This second dimension eminently encompassed concepts related to family, described by appreciation and removal of the nuclear family. These are situations that are not restricted to dentistry course, but whose consequences fall on the universe of college graduates.

Studies show that graduates who live away from their parents exhibit higher levels of stress observed (Tangade et al., 2011; Sedky, 2012). The removal of the family environment, although non-directly linked to the history within the university, causes changes that require an effort of adaptation of the individual to cope with new obstacles. However, these difficulties can be valued and considered an essential part of the admission experience to higher education, since they are associated with the sense of autonomy and maturity (Teixeira et al., 2008). This fact corroborates the findings of this study, since the said detachment was appointed as a causal factor in the etiology of stress.

"The fact of living alone and away from home also weighs, because I need to solve all home things too and not just the college stuff." (1 $1^{\text {st }}$ year student)

"In my case what generates stress is living abroad and alone, because you do not have liability only college, that's necessary to pay account, cooking, washing, ironing. Living with strangers is also complicated.”

(Last year student)

As an unprecedented way before Brazilian studies related, but previously pointed internationally (Acharya, 2003), the search for an effective academic achievement, aiming not only personal satisfaction, but also the recognition of close relatives was highlighted as an influencing agent. The reports revealed that this constant psychological intimidation has considerable effect on eminent stress levels presented in this study.

"[...] Our house requires a lot of people, and I want to please all of my family [...] the fear of not doing well to please people nearby stresses me.” (1 $1^{\text {st }}$ year student)

\section{Conclusion}

The stress was significantly present in the undergraduate dentistry academic environment, manifesting on different frequencies and levels of evolution during the times of the evaluated university career. The analysis of the perceptions of students regarding the etiology of stress situations suggests the suitability of pedagogical and curricular practices exercised by educational institutions, and the rethinking of teaching performance, in order to consider the notes exhibited by respondents. Although in a less intense way, academic perceptions showed the analogy between stress and family issues, implications that cannot be answered by this study.

\section{References}

Acharya, S. (2003). Factors Affecting Stress among Indian Dental Students. Journal of Dental Education, 67, 1140-1148. 
Aguiar, S. M. (2007). Prevalência dos sintomas de estresse e de depressão nos estudantes de medicina e odontologia. Diss., Fortaleza: Universidade de Fortaleza.

Al-Saleh, S. A., Al-Madi, E. M., Al-Angari, N. S., Al-Shehri, H. A., \& Shukri, M. M. (2010). Survey of Perceived Stress-Inducing Problems among Dental Students, Saudi Arabia. The Saudi Dental Journal, 22, 83-88.

http://dx.doi.org/10.1016/j.sdentj.2010.02.007

Al-Samadani, K. H., \& Al-Dharrab, A. A. (2013). The Perception of Stress among Clinical Dental Students. World Journal of Dentistry, 4, 24-28. http://dx.doi.org/10.5005/jp-journals-10015-1197

Al-Sowygh, Z. H., Alfadley, A. A., Al-Saif, M. I., \& Al-Wadei, S. H. (2013). Perceived Causes of Stress among Saudi Dental Students. King Saud University Journal of Dental Sciences, 4, 7-15. http://dx.doi.org/10.1016/j.ksujds.2012.11.002

Badran, D. H., Al-Ali, M. H., Duaibis, R. B., \& Amin, W. M. (2010). Burnout among Clinical Dental Students at Jordanian Universities. Eastern Mediterranean Health Journal, 16, 434-437.

Bardin, L. (1979). Análise de conteúdo. Lisboa: Edições 70.

Bassols, A. M., Sordi, A. O., Eizirik, C. L., Seeger, G. M., Rodrigues, G. S., \& Reche, M. (2008). A Prevalência de Estresse em uma Amostra de Estudantes do Curso de Medicina da Universidade Federal do Rio Grande do Sul. Revista Hospital de Clínicas de Porto Alegre, 28, 153-157.

Calais, S. L., Andrade, L. M. B., \& Lipp, M. E. N. (2003). Diferenças de Sexo e Escolaridade na Manifestação de Stress em Adultos Jovens. Psicologia: Reflexão e Crítica, 16, 257-263. http://dx.doi.org/10.1590/S0102-79722003000200005

Campos, J. A., Jordani, P. C., Zucoloto, M. L., Bonafé, F. S., \& Maroco, J. (2012). Burnout Syndrome among Dental Students. Revista Brasileira de Epidemiologia, 15, 155-165. http://dx.doi.org/10.1590/S1415-790X2012000100014

Carvalho, L., \& Malagris, L. E. N. (2007). Avaliação do nível de stress em profissionais da saúde. Estudos e Pesquisas em Psicologia, 7, 570-582.

Dahan, H., \& Bedos, C. (2010). A Typology of Dental Students According to Their Experience of Stress: A Qualitative Study. Journal of Dental Education, 74, 95-103.

Fonseca, J., Divaris, K., Villalba, S., Pizarro, S., Fernandez, M., Codjambassis, A., Villa-Torres, L., \& Polychronopoulou, A. (2013). Perceived Sources of Stress amongst Chilean and Argentinean Dental Students. European Journal of Dental Education, 17, 30-38. http://dx.doi.org/10.1111/eje.12004

Gerk, E., \& Cunha, S. M. (2006). As habilidades sociais na adaptação de estudantes ao ensino superior. In M. Bandeira, Z. A. P. Del Prette, \& A. Del Prette (Eds.), Estudos sobre habilidades sociais e relacionamento interpessoal (pp. 181-198). São Paulo: Casa do Psicólogo.

Heinz, K., Damin, E. T. B., \& Silva, R. (2011). Ocorrência, níveis e sintomatologia de estresse em acadêmicos de Educação Física. http://www.pergamum.udesc.br/dados-bu/000000/000000000014/000014BF.pdf

Lazzarin, H. C., Nakama, L., \& Cordoni Júnior, L. (2007). O papel do professor na percepção dos alunos de Odontologia. Saúde e Sociedade, 16, 90-101. http://dx.doi.org/10.1590/S0104-12902007000100009

Lima, M. H. M. (2007). O professor, o pesquisador e o professor-pesquisador. http://www.amigosdolivro.com.br/lermais_materias.php?cd_materias=3754

Lipp, M. E. N. (2000). Manual do inventário de sintomas de stress para adultos. São Paulo: Casa do Psicólogo.

Lipp, M. E. N. (2003). Ch. 1 O modelo quadrifásico do stress. In Mecanismos neuropsicofisiológicos do stress: Teoria e aplicações clínicas. São Paulo: Casa do Psicólogo.

Lipp, M. E. N. (2005). Stress e o turbilhão da raiva. São Paulo: Casa do Psicólogo.

Lipp, M. E. N., \& Malagris, L. E. N. (2001). O stress emocional e seu tratamento. In B. Rangé (Ed.), Psicoterapias cognitivo-comportamentais: Um diálogo com a psiquiatria (pp. 475-490). Porto Alegre: Artmed.

Lu, L. (1994). University Transition: Major and Minor Stressors, Personality Characteristics and Mental Health. Psychological Medicine, 24, 81-87. http://dx.doi.org/10.1017/S0033291700026854

Manolova, M. S., Stefanova, V. P., Panayotov, I. V., Romieu, G., Belcheva, A. B., Markova, K. B., \& Levallois, B. (2012). Perceived Sources of Stress in Fifth Year Dental Students-A Comparative Study. Folia Medica, 54, 52-59. http://dx.doi.org/10.2478/v10153-011-0089-3

Merton, R., Fiske, M., \& Kendall, P. (1956). The Focused Interview: A Manual of Problems and Procedures. New York: Free Press.

Monteiro, C. F. S., Freitas, J. F. M., \& Ribeiro, A. A. P. (2007). Estresse no cotidiano acadêmico: O olhar dos alunos de enfermagem da Universidade Federal do Piauí. Escola Anna Nery Revista de Enfermagem, 11, 66-72. http://dx.doi.org/10.1590/S1414-81452007000100009

Morrison, R., \& O’Connor, R. (2005). Predicting Psychological Distress in College Students: The Role of Rumination and 
Stress. Journal of Clinical Psychology, 61, 447-460. http://dx.doi.org/10.1002/jclp.20021

Oliveira, B. L. C. A., Filha, M. O. F., Monteiro, C. H., Pinheiro, R. V. T., \& Cunha, C. L. F. (2012). Estresse entre graduandos de enfermagem de uma universidade pública federal: Um estudo epidemiológico. Journal of Management and Primary Health Care, 3, 72-78.

Pani, S. C., Al Ascar, A. M., Al Mohrij, S. L., \& Al Ohali, T. A. (2011). Evaluation of Stress in Final-Year Saudi Dental Students Using Salivary Cortisol as a Biomarker. Journal of Dental Education, 75, 377-384.

Pesce, M. K. (2012). Professor pesquisador na visão do acadêmico de licenciatura. The IX Anped Sul, Caxias do Sul, 29 July 2012, 1-13.

Pinelli, C., Garcia, P. P. N. S., Campos, J. A. D. B., Dotta, E. A. V., \& Rabello, A. P. (2011). Biossegurança e Odontologia: Crenças e atitudes de graduandos sobre o controle da infecção cruzada. Saúde e Sociedade, 20, 448-461. http://dx.doi.org/10.1590/S0104-12902011000200016

Polychronopoulou, A., \& Divaris, K. (2005). Perceived Sources of Stress among Greek Dental Students. Journal of Dental Education, 69, 687-692.

Rajab, L. D. (2001). Perceived Sources of Stress among Dental Students at the University of Jordan. Journal of Dental Education, 65, 232-241.

Sedky, N. A. (2012). Perceived Sources of Stress among Junior \& Mid-Senior Egyptian Dental Students. International Journal of Health Sciences, 6, 141-157. http://dx.doi.org/10.12816/0005990

Selye, H. (1965). Stress: A tensão da vida. São Paulo: Ibrasa.

Tangade, P. S., Mathur, A., Gupta, R., \& Chaudhary, S. (2011). Assessment of Stress Level among Dental School Students: An Indian Outlook. Dental Research Journal, 8, 95-101.

Teixeira, M. A. P., Dias, A. C. G., Wottrich, S. H., \& Oliveira, A. M. (2008). Adaptação à universidade em jovens calouros. Psicologia Escolar e Educacional, 12, 185-202. http://dx.doi.org/10.1590/S1413-85572008000100013 
Scientific Research Publishing (SCIRP) is one of the largest Open Access journal publishers. It is currently publishing more than 200 open access, online, peer-reviewed journals covering a wide range of academic disciplines. SCIRP serves the worldwide academic communities and contributes to the progress and application of science with its publication.

Other selected journals from SCIRP are listed as below. Submit your manuscript to us via either submit@scirp.org or Online Submission Portal.
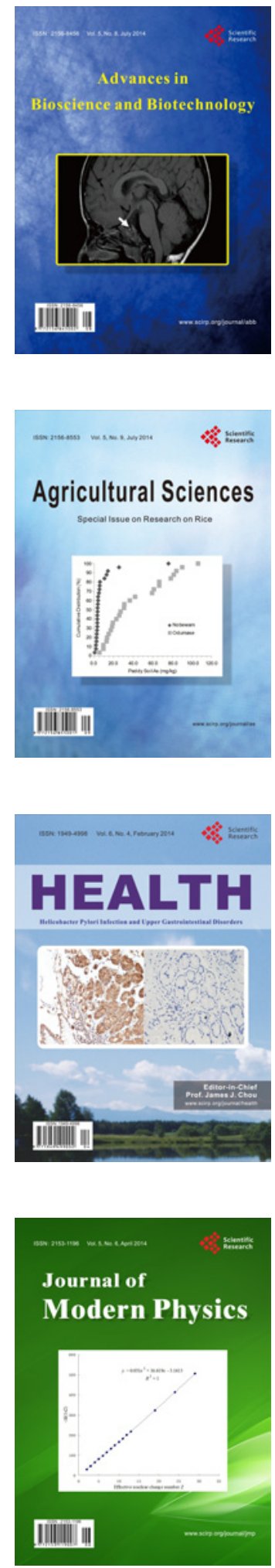
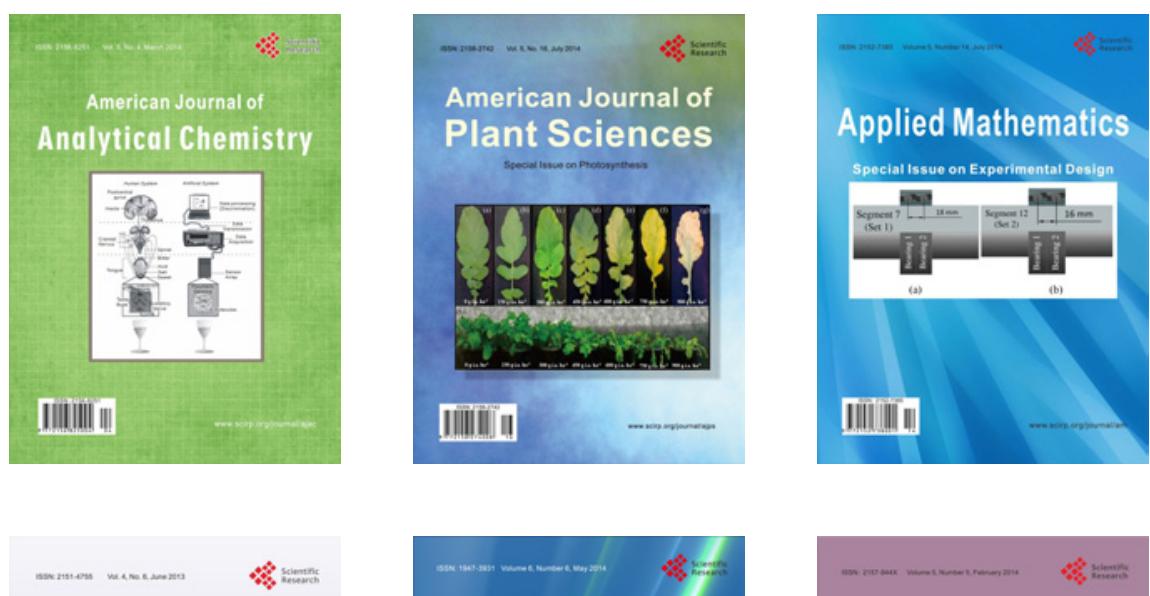

Creative Education
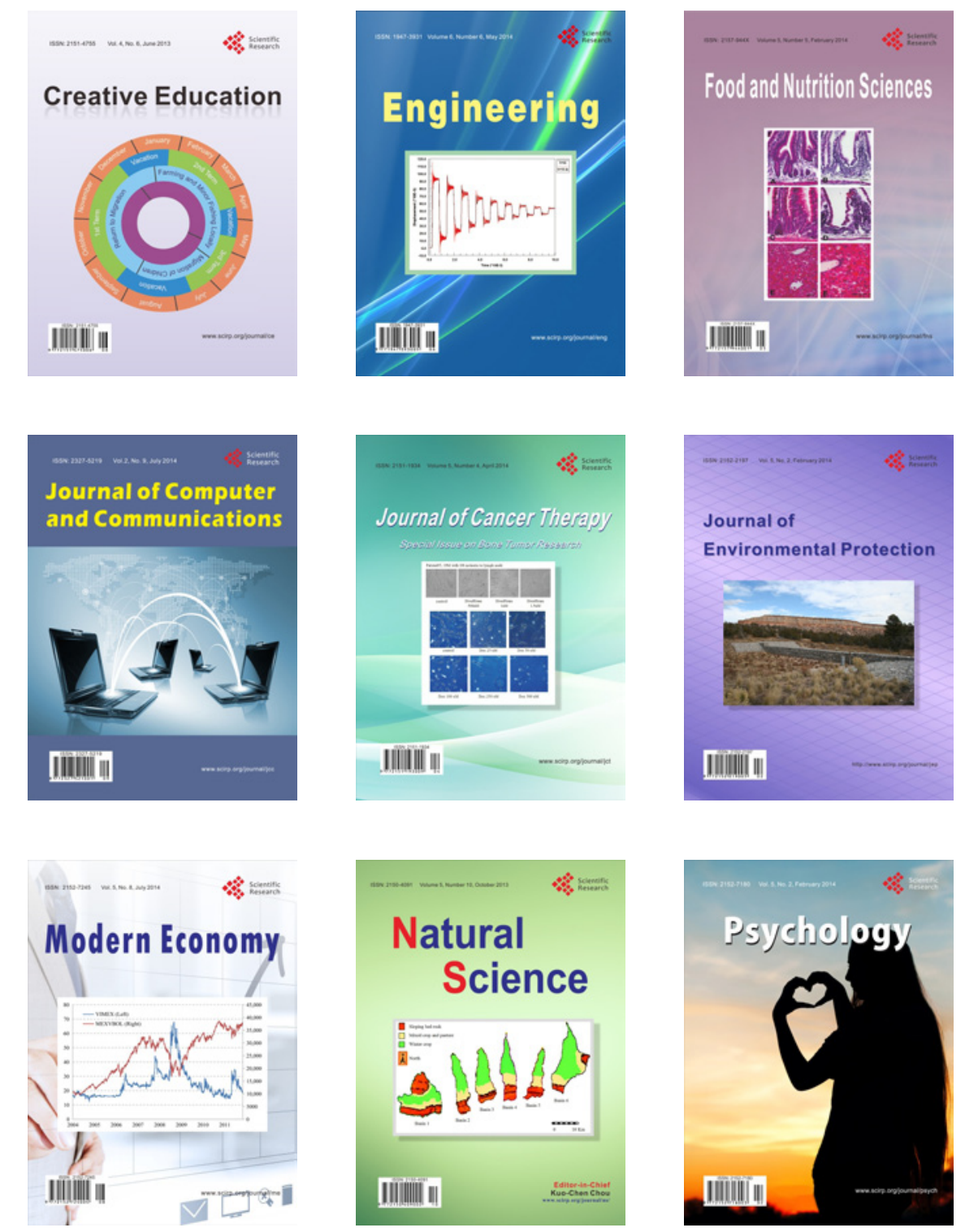